\title{
An Exploration of Karna's Last Days through the Prism of Aristotle's Hamartia
}

\author{
Bharathi S. Rai ${ }^{1} \&$ Manjula K. T. ${ }^{2}$ \\ ${ }^{1}$ Research Scholar, College of Social Science \& Humanities, Srinivas University, Mangalore \\ \& Assistant Professor, Dept of English, St Philomena College, Puttur, Karnataka, India \\ Orcid ID: 0000-0001-9613-4967; Email: raibharathi@ yahoo.com \\ ${ }^{2}$ Research Professor, College of Social Science \& Humanities, Srinivas University, \\ Mangalore, Karnataka, India \\ Orcid ID: 0000-0002-2459-1103; E-mail: manjula.kalyat@gmail.com
}

Area/Section: Humanities.

Type of the Paper: Exploratory Research Analysis.

Type of Review: Peer Reviewed as per $|\mathrm{C}| \mathrm{O}|\mathrm{P}| \mathrm{E} \mid$ guidance.

Indexed in: OpenAIRE.

DOI: https://doi.org/10.5281/zenodo.5526265

Google Scholar Citation: IJMTS

\section{How to Cite this Paper:}

Rai, Bharathi S., \& Manjula, K. T., (2021). An Exploration of Karna's Last Days through the Prism of Aristotle's Hamartia. International Journal of Management, Technology, and Social Sciences (IJMTS), 6(2), 133-146. DOI: https://doi.org/10.5281/zenodo.5526265

International Journal of Management, Technology, and Social Sciences (IJMTS)

A Refereed International Journal of Srinivas University, India.

CrossRef DOI: https://doi.org/10.47992/IJMTS.2581.6012.0159

(C) With Author.

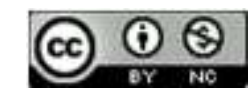

This work is licensed under a Creative Commons Attribution-Non-Commercial 4.0 International License subject to proper citation to the publication source of the work.

Disclaimer: The scholarly papers as reviewed and published by the Srinivas Publications (S.P.), India are the views and opinions of their respective authors and are not the views or opinions of the SP. The SP disclaims of any harm or loss caused due to the published content to any party. 


\title{
An Exploration of Karna's Last Days through the Prism of Aristotle's Hamartia
}

\author{
Bharathi S. Rai ${ }^{1} \&$ Manjula K. T. ${ }^{2}$ \\ ${ }^{1}$ Research Scholar, College of Social Science \& Humanities, Srinivas University, Mangalore \\ \& Assistant Professor, Dept of English, St Philomena College, Puttur, Karnataka, India \\ Orcid ID: 0000-0001-9613-4967; Email: raibharathi@yahoo.com \\ ${ }^{2}$ Research Professor, College of Social Science \& Humanities, Srinivas University, \\ Mangalore, Karnataka, India \\ Orcid ID: 0000-0002-2459-1103; E-mail: manjula.kalyat@gmail.com
}

\begin{abstract}
Purpose: The Mahabharata by Vyasa and the Iliad by Homer both have a surfeit of Heroes. The two great heroes are Karna from the Mahabharata and Achilles from the Iliad. They have a few things in common as their lives are heavily influenced by fate. As fate is inescapable, they confronted their death head-on. The figures of Karna and Achilles stand out dramatically in both Indian and Greek mythology respectively casting everyone else in the gloom, thus making both the masterpieces incomplete without these heroes. Though these spartan heroes were invincible due to their origin, they lay their lives in Kurukshetra and Trojan wars respectively. They decided to be glorious despite knowing the fact that they would die in the battle. Few characters in the ancient literature have been drawn with such perfect skill and insight into human nature as Maharathi Karna, a character who has never been truly understood, has been continually misinterpreted despite the completeness, candor, and clarity of the amazing Epic in providing us with specifics of his existence. The most important aspect of his life narrative which is often overlooked or glossed over by modern writers which has far-reaching implications is that Karna was born out of wedlock and so cast away at birth. His adroitness and the values he lived and loved for standing him in good stead for a hero.

Design / Methodology/Approach: The paper is prepared by accumulating secondary data from educational websites and written articles. The study shall be carried out with the use of Research Journals, Scholarly Books, Doctoral Theses, and websites. This qualitative research is carried out by studying and interpreting the existing knowledge on the subject using the keywords "Karna", "Epic", "Tragic flaw", "Battle", "Loyalty" which are accessible in online articles, peer-reviewed journals, publications and a variety of related portals.
\end{abstract}

Findings/Result: Karna's entire life was spent trying to figure out who he was and to find an answer to the same. Karna's life also shows us how life is full of unrelenting choices; the options being limited. Friendship with someone who has aided at times of need and to whom one has sworn lifelong loyalty and friendship is admirable, but there must be a fine line drawn between this duty and other, more important responsibilities. Karna is, without a doubt, a figure who, in Aristotelian terminology, possesses the classical features of a tragic hero, as well as a figure with a great deal of literary potential.

Originality/Value: This paper attempts to make a sincere study of Karna as a tragic hero under classical examples of Aristotle's 'Hamartia' where a hero wants to 'Triumph' but while doing so he commits an intentional error and ends up achieving exactly the opposite with disastrous results. The story of the life of Karna is pre-eminently great nevertheless fate and destiny played an unwarranted and calamitous game facilitating the reader of the Epic to identify himself or herself with the Tragic Hero.

Paper Type: Exploratory research paper.

Keywords: Battle, Epic, Flaw, Karna, Loyalty, Tragic.

Bharathi S. Rai, et al, (2021); www.srinivaspublication.com 


\section{INTRODUCTION :}

Mahabharata, a magnum opus has caught the imagination and the collective consciousness of the young $\&$ the aged, the educated \& the illiterates, the elites $\&$ the common folks of India in an equal measure of intensity \& reverence over thousands of years. No literary work in the world can boast of standing alongside the Mahabharata in terms of magnitude or significance. The renowned western epics- Iliad \& Odyssey of Homer are dwarfed by the enormous volume of the Mahabharata. They are treated equally to some episodes of the matchless Indian epic. With over one hundred thousand verses, Mahabharata in terms of volume scores eight times more over the combined volume of Iliad \& Odyssey; three \& a half times more over the Bible. Mahabharata is a mammoth literary work from the divine stable of Maharishi Vyasa. Winternits, M. a western scholar says, " Mahabharata, as a whole, is a literary monster" [1].

The Mahabharata is said to be the world's greatest show on earth. Although Vedavyasa is credited as the notional author of the epic classic, it was shaped by a plethora of authors over many generations. They, on the other hand, remain nameless and unheralded until this day. They have left their imprint on the great epic, but there are no signatures to show it. As a result, the Mahabharata is a community effort that embodies India's inherent essence. It is, in its own words, "the hallowed history of the Bharata, exquisite in language and meaning," making the slightly overstated claim that "what is not in it, is not to be found anywhere [2]. To fully appreciate its rich imagery and dramatic intonations, it must be read in Sanskrit. Those who recite it sonorously and those who listen to it will find it appealing to the ear. The number eighteen has to have had a specific meaning in the Mahabharata. There are eighteen Parvas (Books) in total. The Mahabharata war had lasted eighteen days in all. There were eighteen Akshouhinis in each of the opposing forces (corps). There are eighteen chapters in the Bhagavad Gita [2].

Most of us think of the Mahabharata as a story of a great war centred on the Pandavas, how they suffered at the hands of their cousins, and how Shri Krishna defended them at every turn. But why do we overlook the fact that the eldest Pandava, Karna, was never given his due? How unfortunate and tragic it is that he had to be associated with the very enemies of the Pandavas and how he bore this burden and continued to behave as an exemplary hero, committed to fulfilling his sworn duty.

Karna is a unique character the likes of whom we do not find anywhere else in literature. He was the epitome of virtues such as valour, honesty, friendship, benefaction, austerity, oblation, and emancipator of the oppressed. When these traits were stretched to their maximum, they blended and manifested in Karna. Arjuna and Karna had a huge rivalry since they were both outstanding archers and warriors, but Arjuna always received praise for his bravery because he belonged to the king's lineage, Karna, while being superior to Arjuna in bravery and martial arts, was ridiculed because of his inferior parentage.

Karna went to Parashurama for his study when Drona refused to accept him as a disciple due to his inferior pedigree and his desire to portray Arjuna as the bravest man on the earth. Parashurama had made a promise not to teach anyone save Brahmins who were well-versed in the subject. As a result, Karna made up the story that he was a Brahmin. Parashurama tried to shape him in his image, but one day he discovered that Karna was not a Brahmin's son. As a result, he cursed him, saying that he would be unable to utilise Brahmasthra, the most powerful weapon when it was most needed for the protection of his life, though Parashurama was upset by cursing him so ruthlessly.

Lord Krishna, who was on the Pandavas' side, tried his hardest to find a peaceful means to prevent the war of Kurukshetra, but Duryodhana was intoxicated by Karna's valour, who was a close friend of his [3]. Kunti's selfishness, however, pushed, transformed Karna into a tragic hero from the day he was born. We've always been curious about Karna's "might-have-been." What would have occurred if Karna hadn't become the person, he is now? If he hadn't given up his natural armour and earrings; if Maharishi Parashurama and the old Brahmin hadn't cursed him; if he had broken his promise to Kunti even once; if he had accepted the fortuitous offer of the serpent Ashvasena during his battle with Arjuna, and so on, the course of history might have been different.

\section{OBJECTIVES :}

This paper highlights the theme of The Mahabharata - the body may perish, values endure. The objectives are

- To explore Karna as a character within the scope of Aristotle's Hamartia.

- To elucidate how the socio-cultural tradition of the time constituted Karna's fate to be a tragic hero. 
- To analyse Karna's error of judgement.

- To analyse his attitude of generosity to a fault, be it of wealth or his own life.

\section{METHODOLOGY :}

The paper is prepared by accumulating secondary data from educational websites and written articles. The study shall be carried out with the use of Research Journals, Scholarly Books, Doctoral Theses, and websites. This qualitative research is carried out by studying and interpreting the existing knowledge on the subject using the keywords "Karna", "Epic", "Tragic flaw", "Battle", "Loyalty" which are accessible in online articles, peer-reviewed journals, publications and a variety of related portals.

\section{HIS BIRTH AND ABANDONMENT :}

Few characters in ancient literature have been drawn with such perfect skill and insight into human nature as Maharathi Karna, a character who has never been truly understood has been continually misinterpreted - despite the Epic's amazing completeness, candour, and clarity in providing us with the specifics of his existence. The Epic tells us in so many words that he was born as an unintended and unwelcome consequence of his mother's extremely overwhelming curiosity, Kunti, who, while still an unmarried virgin living in her parents' house, worked with a hidden sexual charm granted to her by an impulsive and irascible sage in her youth. To her amazement and dismay, the charm worked. She was terrified when God appeared before her in person in response to the call to fulfill her wish, and she pleaded with him to leave her alone and not force her to become the mother of his son. But her pleadings were in vain since her suitor, the Sun God, was adamant in his determination. Against her will and intention, she gave birth to a kid who was as bright as the sun, as strong as iron, and cloaked in natural armour, a proof of his invincibility. The young girl carried the radiant child of the Sun God to the riverbank in the dead of night, placing it in a bejewelled casket, setting it afloat on the river, and leaving it to its fate [4].

The youngster was scooped up on the outside of the hi-brow society's enclave and lovingly raised by Adhiratha, the unnamed superintendent of Royal chariots, and his wife Radha. This is a straightforward and unvarnished account of the "unwanted kid," a well-known figure in romantic literature, and the boy's behaviour as he develops into manhood is completely accurate.

This unfortunate foundling, unwanted by society and cowering under the wings of its foster parents, turns instinctively to avenge itself on society, which had harshly cast it aside while still defenceless, for no fault of its own [5].

Karna's anger is unknowingly but inescapably focused on his brothers, the Pandavas, who have deprived him of all the good things in life: wealth, rank, and the good opinion of society. But it is particularly directed at their common wife Draupadi, the outward embodiment of their worldly pleasures and delight, as well as the divine Draupadi who would have been his had he not been forcibly cast away as a child. He prepares himself for the coming fight, committing himself assiduously to the development of expertise in the handling of arms alongside his siblings and cousins, and easily outperforms everyone except his younger brother, Arjuna, driven by an inner need. As a result, Arjuna becomes yet another target for his wrath. He suffers his first public disgrace during the Royal tournament, which was held to assess the young princes' ability in martial feats. He challenges Arjuna to single combat, believing that he will easily defeat his opponent, but Arjuna's companions refuse to fight since Karna is not born equal to Arjuna, and the challenger is a parvenu, unfit to engage with princes with blue blood coursing through their veins. Karna resents the death that was meted out to him at his birth [6]. However, the war could not be avoided; it could only be postponed. Many years later, when Karna confronts him as the generalissimo of the Kaurava army, Arjuna is forced to take up the challenge again. And Karna and Arjuna meet on the battlefield of Kurukshetra, not in a fake battle as they did on that day at Hasthinapura, but in a mortal battle. Meanwhile, Karna grants his ego complete reign. His shattered vanity pushes him to seek wealth, power, and supporters to aid him in his clandestine revenge. He joins the court of Kaurava and willingly plays the second fiddle to Duryodhana so that he can reclaim the lands that had been taken away from him. His inferiority mentality drives him to confront and attack the noble Bhishma, whom he sees as the vile embodiment of arrogant decorum and prudence [7].

\section{DAANAVEERA KARNA :}

Karna was overly generous. But his proverbial generosity was just a pose, though an unconscious one, to outdo the accredited nobility in their hyped virtue, liberality, and to hear himself lauded to the skies 
by the begging fraternity, as a compensation for the taunts and sneers of the highbrow nobles, proud of their birth, at the Kaurava court. There is also an argument saying Karna lacked truly heartfelt generosity. He was incapable of meaningful sacrifice or sincere charity because his frustration complex was unresolved. During the disastrous game of dice, he joins the rabid throng at Hastinapura's court in persistently shaming and tormenting the inoffensive Draupadi, who had herself done him no damage at any point. On the eve of the Bharata war, when his mother, Kunti, reveals his identity and begs him tearfully to reconcile with the Pandavas, who were his brothers, and thus help to stop the carnage that was about to occur, he remains unmoved, citing his obligations to his foster parents and loyalty to his benefactor, Duryodhana. His unrestrained charity ends up becoming his ruin in the end. Indra, posing as a Brahmin mendicant, takes advantage of his pledge not to refuse any request from a Brahmin and begs him for his natural chest plate and precious earrings, which had rendered him invincible. Karna is caught in the middle of a dilemma. Should he breach his word, as the Sun-God, his presumed father, had urged him to do, or should he relinquish his invincibility? He disobeys his father and opts for the second option, which is typical of him. He clutches the false shroud of charity even tighter around himself and parts with his prized goods with feigned indifference. He would have understood himself as he was and could have remained invincible if he had been capable of understanding his reasons and seeing that his pledge of generosity was a false attitude, as the Sun-God had realised. That, however, was not to be; indeed, it could not be. Because the Ego, in its fight with the Self, i.e., the Super self, cannot win. The Ego can be greatly inflated, even frighteningly inflated, but not eternally. Everywhere, nature has established boundaries. When a bubble is inflated beyond a particular point, it explodes. Who or what causes it to burst? It forms itself and activates a subtle force that causes it to burst. The force, which is just right for the job, seeks out and assaults the bubble's weakest place. This is how it is in nature. The same is true of human personality and the same occurred in Karna's life [5].

Karna refuses to fight while Bhishma is alive, sulking in his tent with an overabundance of faith in his abilities. Duryodhana is thus deprived of any assistance he could have provided during the first ten days of the war, a condition that gave the Pandavas an initial advantage over their opponents despite the overwhelming numerical disadvantages against them. Karna was Arjuna's technical equal, if not greater, in technical skill; yet, he lacked Arjuna's spiritual strength, which sustained him in the hour of trial. Karna's virtuosity is thwarted at a crucial point by a higher power, who strikes him down to aid the struggling and downtrodden adherents of the cause of justice and righteousness by exploiting a gap in Karna's invincible armour [4].

\section{THE FICKLENESS OF FATE AND KARNA'S STEADFASTNESS :}

Modern commentators have made much of the fact that Sri Krishna tells Arjuna to kill Karna while the latter is releasing the wheel of his chariot, which is stuck in a hole in the ground. "Yes, in the entire universe, strange things are just for me, the conceit of fate is just for me," Radheya laughed, recalling something in his head. But it's all right when fate gets entangled when the earth itself tries to consume Karna's chariot, who can pull it up by his arms save Radheya's masculine strength?"[8]. Karna solicits for more time, requesting that his opponent wait until he has freed the wheel. He argues that it is unjust for a man to fight from a chariot against someone who does not have a chariot; it is unworthy of a cavalier like Arjuna. How easy it is to point out flaws in others' behaviour, but how difficult it is to notice flaws in one's own! However, Providence, who rules over men's fates, has no preference for one personality over another. As a result, it consistently metes out justice to everybody, in suitable ways, and through devious routes, with precision. That is, without a doubt, the lesson that the epic poets wish to impart [6].

Some writers, inspired by Karna's valiant courage, deep loyalty, and boundless charity, have questioned the epic's validity, claiming that the character of Karna as presented in the current form of the epic is inconsistent with his fate and the epic poets' critique of his conduct. They attribute this inconsistency to an inversion of the epic theme already mentioned, claiming that in a previous version of the epic, Karna, the son of the Sun deity, was the hero himself, a role usurped in the present epic by another person or persons. The Sun God's instruction was a test of his character, and Karna's reluctance to follow it is ample evidence of his noble nature and lofty idealism. This contrasts sharply with the Pandavas' unchivalrous actions, in which they abandon too easily the high ideals of knightly conduct and honour, and resort to unworthy means to bring about the death on the battlefield of their honourable and chivalrous warriors like Bhişhma, Drona, and Duryodhana. However, such a claim is unfounded and demonstrates a lack of comprehension of the epic poets' epistemology. When the circumstances of 
Karna's birth and early life are considered, the seeming discrepancies in his character, as well as his fate, can be explained [9].

\section{KUNTI'S SECRET UNDER WRAPS AND KARNA'S ADHERENCE TO DHARMIC VALUES :}

Kunti's secret, which she believed she had skilfully buried, unknown to anyone, by severing her connection with her first child at its birth, could not be kept for long, because no secret can bring back to her, after some time, the desired child whom she had snatched from her warm palpitating milkful breasts and unkindly set about on the insensible bosom of the mighty and cold river Ashva. Finally, she had to reveal the secret to the very people she wished to shield from it and its consequences-her children, to whom she felt obligated to seem like a decent, smart, and virtuous mother. First, she had to tell her eldest son, Karna, about her adolescent indiscretion. She hoped that by telling him the huge secret of her small life, she would be able to prevent the repercussions of that deed on her other sons, the five Pandavas, whom she adored. In that, she was doomed to be disappointed, as Karna remained adamant, refusing, forcefully but politely, to comply with her and make himself a scapegoat. After Karna's death, she had to tell the remaining sons the story herself, in the pious hope that his life thereafter would not be a repeat of the horror he had suffered on earth. She had to admit to the world after Karna's death that she was the mother of the fatherless kid, something she had failed to do during his birth. Is there anything more silently terrible than this? When she had unburdened her soul to her beloved children, she was finally free of the tormenting force of that secret, which had helped grind to dust the blooms of youth and chivalry of India's heroic age through devious pathways. Could the epic perform its job of catharsis more dramatically and emphatically for those who can follow its language and comprehend its deep significance and crucial message to mankind? [5].

\section{KARNA AS AN EXISTENTIAL HERO :}

Karna has been described as an existential hero who stands out like the Pole Star gleaming in its lonely splendour among the rest of the stars. By all accounts, he was a true Veera (hero), praised by both friends and foes. In equal measure, he has been referred to as Yuddhaveera (battle-tested hero) and Daanaveera (kind benefactor). His flaws and virtues were equally endearing. He was a 'vociferous' and 'eloquent' guy, according to his mother Kunti, who described him as a 'truthful guy, valiant, and praying,' frightened of God but not of men. To some, he was a courageous, heroic, and praying man, while to others, he was an obnoxious braggart who matched insult with insult. He defined his vigour and bravery as the personal dharma' of a hero like him, and he regarded them as the highest in his scale of values. The man had been defined by these features. Karna, in all his majesty, is a tragic figure who deserves to be pitied for the circumstances into which he had been thrust by fate and over which he had no control. He was a vital cog lubricating the Kuru power system, which he had no influence over. He was an insider, but it bothered him when his friends and foes never failed to remind him of his poor standing due to his 'birth.' Kunti, his mother, claimed him late in the day, but he refused to buy her story. Krishna had tempted him with the Pandava throne, but he had turned him down [2].

Karna had predicted his death on the battlefield, but he had refused to change his mind. He was far too gentlemanly to haggle or bargain. Arjuna, his younger brother, was the sole target of his ill will. He needed to make amends for his previous insults and insinuations. He'd even told himself years ago that he wouldn't wash his feet until he'd settled his accounts with Arjuna. It was the same sibling rivalry all over again. Karna and Arjuna, the best of the two men, had finally met face to face. Others saw it as a display fit for gods to witness, and they were left wonder-struck and awe-stuck in anticipation of the upcoming greatest display on earth. Karna's day, on the other hand, was not to be. He died in the end, yet even in his most desperate circumstances, he looked majestic [2].

Bhishma had lavished praise on Arjuna when speaking with the Pandava messenger. In his opinion, no one in the three worlds could compete with Arjuna on the battlefield. It was all uttered in front of Karna to enrage him, who was full of rage and arrogance and haughtily spoke to the messenger, ignoring Bhishma on purpose. He had described the Pandavas as plain foolish and dharma-breakers for demanding a share of their fathers' and grandfather's kingdoms, and if they want war, then so be it. Bhishma had no qualms about censuring Radheya to remind him of the dharmic Pandavas' terrible consequences. The grandfather was in full swing, and there was nothing that could stop him from cornering Karna, leaving Karna with little choice but to rebound on Bhishma's take. Bhishma understood better, and he was to remind Karna of Krishna's inherent God-given and demonstrated capacity as the Pandavas' pillar of strength: "You will not be overcome by exhaustion when fighting. 
There will be no obstacles in the sky or on the water. Weapons will never be able to pierce your skin" [2].

Karna, on the other hand, could not be stopped. He had shown himself against all odds of birth and upbringing, and he had further solidified his position by pledging his complete loyalty and strategic alliance with his friend Duryodhana. Various conflicts and entanglements between Bhishma and Karna occurred on other occasions. While deliberations on war strategy and tactics were taking place, Karna rushed into the fray and offered to launch a war against the Pandavas on his own. He pledged to carry out the cleansing mission almost entirely by himself, aided only by a small group of "elite soldiers". Bhishma merely sneered and told him straight in the face that all the Kuru Maharathas, including himself, would be dead before Karna even thought of killing his Pandava foes. "Let him listen to the consequences, Karna said as he stood up, straightened his entire form, and prepared to respond to the grandfather's harsh words: "Let him listen to the consequences in the assembly hall, but not in the war, my grandfather will see me". He simply walked out of the room in protest. Bhishma was being cruel in his nitpicking and slamming Karna for his low-born Suta connection on that specific occasion [2].

\section{VALUES AND VALOUR BLENDED IN THE BLOOD :}

Karna's life must be examined from his point of view. Karna is a suta, a member of one of the society's lower jatis (castes) in the epic's social system, as he is the son of a charioteer couple. Karna does not belong to the Kshatriya varna, or "aristocratic warrior class," even if his parents do. Karna's suta caste is likewise poor, as well as pratiloma, or "against the grain" caste [10].

At the same time, the epic's audience is aware that Karna is the result of Surya, the sun god, and an unmarried virgin named Kunti of the blue-blooded warrior (Kshatriya) class. To hide the fact that she had a child before marriage, Kunti abandons the infant in the Ahsva river, but he is taken to the bosom, adopted, and raised adoringly by Adhiratha and Radha, the childless (suta) couple [10].

As Karna grows older, he develops exceptional military skills while also becoming increasingly incensed of social hierarchy and injustice, as well as prejudice toward his suta-ness. These two tendencies intersect when he gate-crashes a military tournament, an event intended to honour the Kuru princes' completion of their military training, two classes united by blood but separated by passionate enmity. The tournament has advanced a long way by the time Karna arrives; in fact, Arjuna, the tournament victor, is ready to be crowned. Karna enters the showground and immediately causes a stir [10].

Just before they're about to fight, the story takes a pivotal turn: "What is your Kshatriya lineage?" Karna is questioned by Kripa, a teacher of the princes. Karna had no other option except to lower his head. Then, unexpectedly, Duryodhana, the firstborn of the Kaurava brothers, steps forward and declares Karna a Kshatriya, essentially ending any animosity toward Karna and Arjuna's battle. (From then on, Karna stays Duryodhana's thankful servant.) At that particular moment, Karna's father, Adhiratha, enters the arena. Karna respects his father by bowing down to him without hesitation. And while this causes commotion among the players and the crowd - there began jeering words darted at Karna, "the charioteer's son, charioteer's son," as well as pleas for aid - the tournament eventually collapses, and Arjuna and Karna's showdown is put on hold. When Bhima notices Karna kneeling to his father Adhiratha, he sneers, "you [would] best stick to the whip that suits your kin" [10].

\subsection{Right Person on the Wrong Side:}

Karna never forgives the Pandavas for their decisions, and his hatred and envy for them grows more and stronger over time. Beating Arjuna becomes one of his life's ambitions. This brings the epic's audience to the point where Krishna meets Karna just before the war starts. Krishna begins by informing Karna that he is a Pandava brother. Despite the fact that he was nurtured by the Suta family, he was born to Kunti, the Pandavas' mother. Karna can be crowned king of the entire kingdom right away if he agrees to be the eldest: both the Kauravas and the Pandavas will attend him, and he will even get to marry the Pandavas' common bride! According to Krishna, the Kauravas will not dare to question the Pandavas without Karna. Karna responds that his father Adhiratha adopted him because he adored him, and that his mother Radha breastfed him because she treasured him. Furthermore, Karna considers that abandoning the king (Duryodhana) who has provided him with refuge and honour for many years would be reprehensible [11].

Karna then asks Krishna to keep the information that Karna is Kunti's son hidden from everyone so that Pandava Yudhistira can become king. Krishna reacts by expressing amazement that the offer of a kingdom has not tempted Karna. Nonetheless, the conflict was forecasted a long time ago, and it will 
take place to usher in the Fourth Epoch (the Kali Yuga), the most debauched and decrepit period in human history [10]. As he speaks, Karna is making a very careful and conscious decision. It is evidently a difficult decision made with significant thought, sensitivity, and self-consciousness. We should not be deceived into assuming that Karna has a naive view of the cosmos because he refuses Krishna's advice [10].

Kunti, Karna's biological mother, approaches him now and announces herself as his mother, as well as seeking to introduce him to the Pandava side of the family. Surya double-checks Kunti's words and encourages Karna to listen to her. Karna did not waver as he was steadfast in his convictions. Karna, like Krishna, reiterates that he must maintain the course out of loyalty [12]. When the war breaks out, Karna arrives late, fights well, defeats her sons while sparing their lives just as he promised Kunt leaving Dharmaraja humiliated. The words of Dharmaraja himself help us understand Karna's grandeur. He approached Hari fearless and thrilled with a hard-won victory, his eyes flashing with pleasure pearls.

He exclaimed, "Keshava!" I was afraid; I had never imagined Arjuna would be able to overcome this difficulty and Karna would one day perish in the battlefield" [8]. Mother, you have sentenced us to an eternal hell by keeping your secret hidden from us. Why have you drowned us in unfathomable depths of heinousness for which there is no atonement? There is no redemption on earth or in heaven for someone who has murdered his brother. Is there a more horrible sinner than me, who slew his brother in order to take his kingdom? Is there a soul more cursed than mine, who made the killing of his brother his life's goal? [13].

\subsection{Resolute Conviction:}

Duryodhana orders Karna to use his infallible weapon on Ghatotkaja, the son of Pandava Bhima, who threatens to slay the Kaurava army; Karna does so, even after knowing that it is through that only weapon he can beat Arjuna. When Arjuna and Karna finally meet, their battle is dragged out and ultimately inconclusive. Karna shoots a snake-shaped arrow that escaped from a jungle that Arjuna had previously burned down. As Krishna, Arjuna's charioteer, lowers the ground beneath Arjuna's chariot, the snake arrow only dislodges Arjuna's crown. The snake arrow returns to Karna and requests to be shot again, but Karna refuses because it is against Kshatriya law to refire a weapon.

"How cruel!" With a smidgeon of a smile on his face, Radheya said. So, what are your thoughts. All the means of conquest are in the hands of the individual. Would I, the man, fight against man even if I was collaborating with snakes back then? Is it necessary for me to give up any faith I've had up to this point? With your help, I'd easily win, but how would I show myself to the rest of humanity? The world would say that Karna has mislaid all of his qualities; the sinner slew the opponent with a serpent [8].

Karna's chariot wheel becomes stuck in the mud, and he requests Arjuna to grant him time to free his chariot, as it is the required Kshatriya discipline. Karna is defenceless due to Parashurama's curse that he would fail to recall the use of Brahmasthra, the apex of the brilliance of his (Parashurama) instructions at the last possible moment. With the help of Krishna, Arjuna kills Karna. One arrow pierced Karna's neck precisely as he set his sight on the sky and focused on the Sun, and light erupted from the body! Once the house of oblation was severed from the body, the light that soared became one joined into unity with the Sun God [8].

\subsection{Commitment to Personal Values:}

Maharathi Karna from the ancient Epic Mahabharata, following in the footsteps of Greek hero Achilles and Elizabethan tragic heroes such as Hamlet, King Lear, Othello, and Macbeth, Maharathi Karna piqued my interest and compelled me to learn more about him. Karna, who was marginalised throughout the epic and was constantly mocked due to his low caste, emerges as the true hero in the end. Although Karna was the king of Anga and had the divine thread linked to him, he was mocked by society, even by the mighty and moralistic Pandava princes. He was taken advantage of because of his serene honesty, which he cheerfully embraced by adhering to his moral beliefs and surrendering his Kavach and Kundal as brahmin bhiksha when Indra came in disguise. Now I understand, you are none other than the King of Gods, and you have come to grant new ascendance in my oblation because you are pleased. The heaven has truly come for alms to the earth, thanks to my reputation, which has drawn you down to the earth [8]. In and of itself, this event is the pinnacle of injustice and dubiousness. 


\subsection{Soul Shattering Revelation by Kunti:}

When Lord Krishna realised that slaying Karna in a righteous manner in combat would be impossible because he was invincible, even Arjuna could not kill him. So, it was Krishna's plot to send Kunti for Kunti Sandhana to emotionally break him. It is truly soul-shattering to hear Karna when he says:

"Consider, what punishment the world would have meted out, other than notoriety and blame. You would have become pure gold melted in the fire, just as dust imperfections would have blown away and blended in the air "

"Probably, society would have hit you like a tonne of bricks, and a dark cloud of misery would have descended upon you. Almost certainly, you would have had to abandon your family, and almost certainly, you would have had to flee from the house."

"But, despite the disasters, had you adhered to your guns, had you stood up boldly in front of the world, drinking nectar, had you not been terrified by seeing poison, for the love, had you paid the price?"

"You would not have stayed in the palace to enjoy the queenly joys; you would have been rearing me under a tree. Oh, sweet lady! You would have amassed immense global acclaim, and you would have been referred to be a woman of modesty and character".

"I would have been marching with my head held high in pride, not bowed and guilty. What would not have been available to Karna the incarnate if he had landed on your loving lap? But now that everything has been completed, it is pointless to mourn; to regret the past is to lose one's life. What has gotten away, and how do you get it back? How far back in time might I go? "What should I do?" You have come to give me today with tears the fortune that you had stolen by becoming harsh. However, the Ganga's water has turned poisonous, making compromise difficult." "Why do you open it now, in the fourth stage of life, the secret you never opened? Allow everything to be covered, and let me endure the rest of the contempt" [8].

Karna's grandeur is revealed to the world through these incidents, which show that he was too loyal to Hastinapur's throne and too loyal to Duryodhana's friendship, as he had given him the social rank like that of a Kshatriya. Karna's two strong principles ended up being a tragic flaw in his remarkable life. It was as a result of this that Lord Krishna observed a dubious approach as the best way for breaking Karna.

Mother, I shall fight my brothers for Suyodhana. Now I'm not so vengeful that I'm willing to kill my foes. The anger needed for defeating the enemy is also robbed from me. Even yet, the virtuous way remains the righteous route. Anyone can die at any time. But how can one erase one's reality? That is something that not even God can accomplish. I shall fight against my brothers with all my might and prowess, regardless of my life, according to rightful laws as becoming a virtuous man. There will be combat between Karna and his younger brother Arjuna in this war. On the one hand, by killing Arjuna, I might entice cursed satisfaction. Otherwise, he may achieve eternal glory by killing your son. The conflict will stop if one of your sons dies, and only if one of your sons dies. I'll join you if I survive. Permit me to travel with a clear mind, Mother [13].

Not only the human beneath the thick quilt of warrior emerges in front of his biological mother, Kunti - A living driving force of all his lifelong humiliations and insults, but tragic hero also makes himself prominent in the audience's mind as he wilfully embarrasses Kunti's wish of letting Arjuna live, thus he says "Let the son of Pandu be victorious and live forever. I choose to stay with the hopeless desperate one's" [14]. In Karna's character there lies ample space for critical analysis and discussion as significant as any other characters in the epic open to various interpretations from vivid perspectives. However, it performs as a universal truth that he remains a marginalized character despite being empowered in his respective situation. Karna embraces his fate to be killed wrongfully on the battleground, thus achieving recognition as one of the greatest Warriors of all time [6].

\section{KARNA AS A TRAGIC HERO :}

A Tragic Hero is a man whose misfortune is brought about not by vice or depravity but by Error of Judgement [15]. Svein Østerud elaborates on the concept of hamartia from the chapter of Aristotle's Poetics is one of the few passages in Greek literature that has been meticulously analysed and discussed. It's not simply because of the text's terse and elliptical style that researchers can't agree on what the Aristotelian hamartia means; it's also because hamartia, like every other technical term in the Poetics, symbolises Aristotle's understanding of Greek tragedy. As Aristotle is a theoretical rather than an objective historian in Poetics, we can scarcely develop a correct notion of hamartia by analysing the real practise of tragedy. Instead, we should try to grasp the gist of his tragedy thesis. It is therefore necessary to look at hamartia in the context of Aristotle's tragedy theory, as well as to see if the 
Aristotelian idea of hamartia is appropriate for tragedy. The numerous scholars who have expressed an opinion on hamartia can be split into two schools of thought: those who associate hamartia with 'tragic flaw' or 'moral weakness,' and those who reject that hamartia has any moral overtones and say that it simply means 'error of judgment.'

In his book "Aristotle: On the Art of Poetry," I. Bywater references two texts from the Nichomachean Ethics to argue that hamartia is a "mistake" or "error of judgement," not a "moral fault" or "infirmity of character" in the Aristotelian sense. However, whether these passages corroborate Bywater's claim is debatable because guilty acts are also covered by the term hamartia or its cognates. In Chapter 13 of Poetics, Aristotle introduces the concept of hamartia. One of Aristotle's objectives in this chapter is to determine what conditions are required for the tragic impact to occur. When one takes a closer look at the chapter, one will notice that it's all about how the tragedian may best achieve the perfect impression of tragedy. In chapter 6, Aristotle introduced the idea that a tragic story should elicit "pity and horror," and he returns to this theory in this chapter as he examines the various character and storyline combinations.

Aristotle appears to avoid a tragic plot that can be read in terms of well-defined moral categories: a reward for the good and punishment for the bad (so-called poetical justice), the virtuous dying, and the wicked flourishing. As a result, narratives that engage our moral awareness right away, giving us the sensation that "justice has been served" or "there is no justice in the world," are rejected. Taking a moral stance, as both of these examples show, is to see the story from the outside; the viewer would be unable to see how the events on stage affect him and his life. It is a typical experience that when we pass a moral judgement on another person, whether favourable or unfavourable, we are also erecting a barrier between ourselves. We place him in one of two categories: superior or inferior to ourselves [16].

"There is no doubt that Aristotle meant hamartia to represent a moral fault or failure of some sort," writes R.D Dawe in his scholarly arguments on Hamartia. Despite the fact that every student of Greek or even Shakespearean tragedy is familiar with the term, it is nonetheless replete with misinterpretations. Even in largely civilised parts of the world, hamartia might be interpreted as a character fault. On the other hand, is there any other kind of emphasis on hamartia? The word is used to describe the right character of a tragic hero. Someone has to go from good fortune to bad fortune: traditionally, there are two well-marked routes to misfortune: (a) the well-deserved punishment of the transgressor, which, according to Aristotle, is not a suitable subject for tragedy and does not necessarily involve any pity or fear; and (b) the well-deserved punishment of the transgressor, which, according to Aristotle, is not a suitable subject for tragedy and does not necessarily involve any pity or fear. (c) the ruin of a fine person like you or me as a result of some blunder [17].

Aristotle makes it clear in the introduction that the tragic hero should not be a paragon of virtue and justice, nor should his misery be caused by his wrongdoing. Aristotle prefers a hero who is halfway between good and evil, a man who is ordinary or similar to us in terms of morals. Hamartia is more of an act than a personality trait. As previously said, the individual should be neither exceptional nor dreadful, but rather somewhere in the between. As a result, hamartia imbues the action with a moral haze, making it impossible for the audience to decide whether the hero is guilty or innocent. As we are shown, our desire to identify with the hero is conditional on him not appearing as a criminal or a saint, but as morally equal to us [16].

Apart from what he says about "error" being conducted by the tragic hero, the other traits which according to Aristotle define a hero are

- He must suffer more than what he deserves.

- His fate must be greater than what he lives in his life or what he deserved.

- He must be doomed from the beginning of the plot but does not possess any responsibility for possessing his flaw

- Must be noble but imperfect at the same time allowing the audience to connect with the character [18].

As we explore the character of Karna, as a tragic hero through the prism of HAMARTIA a gallery of tragic heroes passes across our mind. To mention the Greek hero Achilles in Homer's Iliad both Karna and Achilles are made of such a material that they would gladly give their life rather than go through a situation where they were insulted. For example, when Agamemnon took Achilles' trophy of pride, the lovely Briseis, Achilles was immediately overwhelmed with fury. The admission and death of Patroclus at the hands of Hector, as well as the epic's climax, the Achilles Hector clash, all take place during Achilles' fury [19]. 
Achilles had no desire for material gain, and Karna appears to have a temperament similar to Achilles' in that he is not lured by earthly possessions. In comparison to Achilles, King Agamemnon's psyche is heavily influenced by monetary gain. Agamemnon was interested in the monetary value of things.

When compared to Karna, the situation is similar. Duryodhana is hell-bent on achieving material success. Karna simply backed Duryodhana to avenge his shame and gain heroic fame. Similarly, Achilles has joined the Trojan expedition in the hopes of achieving great glory. Achilles is completely dedicated to heroic achievement for its own sake, not for the benefits, it delivers in terms of monetary wealth, social status, righteous revenge, or the defence of loved ones. He prefers a little period of glory to a protracted period of obscurity.

Karna, too, chose a life of grandeur and honour. Because he kept his word, his courageous life shines brightly. Krishna encounters Karna before the battle of Kurukshetra and tells him the truth about his birth. Karna requests Krishna to keep the circumstances of his birth a secret because he knows it would demoralise the Pandavas. Duryodhana, Karna claims, is the one who defended his honour while others belittled him. It was now time to repay Duryodhana's loan. As a result, he remained Duryodhana's loyal servant.

Karna stands apart from the crowd because of two characteristics he possesses: loyalty and kindness. Because of the unusual turn of events that deny him his due role, his character demands sympathy. Karna's life is described by Irawati Karve as follows: "Karna has no definite position in society." He had toiled his entire life to achieve what he believed was his rightful standing, and his bitterness sprang from the fact that he had not succeeded [20]. He has suffered immensely as a result of his burgeoning ambition, and he is unwilling to spend the rest of his life as a suta. Even his affiliation with Duryodhana and subsequent Anga-rajaship failed to raise his social status. Karna is thus a classic example of fate's harsh hand.

Before the battle of Kurukshetra, Indra dressed as a Brahmin approaches Karna and asks for the earrings and the breastplate. Karna takes away true Kshatriya's divine characteristics when he refuses such a request. In exchange, he receives a missile that is guaranteed to destroy any god or human target.

It's worth noting that neither Achilles nor Karna had any personal desire to participate in the Trojan or Kurukshetra wars, respectively. Because Paris eloped with Helen, the Trojan War was waged. Menelaus then launched the war on Troy, in which all Greeks were expected to take part. Achilles claimed that he would not participate in the fight after being humiliated by Agamemnon. When Ghatotkaja, the son of Bhima and Hidimba, pressed Duryodhana, he requested Karna to use shakti, the boon provided by Indra, which he had set aside to kill Arjuna. When Patroclus walks to the battlefield alone, Achilles is concerned for his cherished friend. As a result, he prays to Zeus for his loved friend's protection.

Achilles, on the other hand, is completely prepared to accept and embrace his death once Patroclus is dead. He no longer speaks of grandeur, but fate.

Karna, on the other hand, fights Arjuna and dies. Karna made various assertions about how destiny had won just before he died. Because he can't be grounded to dust, Karna unites with the sun. He returns to his source, the Sun.

To summarise, both Achilles and Karna are born great, but they both suffer from their awful fate. They recognise the difference between good and evil, but, like Adam and Eve in Milton's Paradise Lost, they eventually embrace what is wicked, what they want to despise. Karna with strong characteristics of loyalty and friendship is fuelled by his egotism, whereas Achilles' excessive pride feeds his rage. Both of these heroes are tragic in the real sense of the word: they are involved in awful acts, they get acclaim, but they are doomed in the end. Achilles and Karna, on the other hand, are ultimately restored to their former glory and heroic stature [21].

\subsection{Karna Compared with Shakespearean Tragic Heroes:}

When considered the tragic hero of Shakespeare's play Hamlet, Hamlet's fatal weakness is his failure to act quickly to assassinate Claudius, his uncle who is the murderer of his father. Procrastination is his tragic flaw. His constant awareness and skepticism prevent him from completing the task at hand.

In the play Macbeth Macbeth's ultimate weakness is his unbridled ambition, an unquenchable desire for power and rank, particularly to be the king, which is more important to him than everything else in life. He is willing to give up everything he has in life to obtain the throne and the crown. King Lear's hamartia (tragic defect) in King Lear is his arrogance and excessive pride. Jealousy is frequently considered as Othello's tragic weakness in Othello although other tragic weaknesses include insecurity and bad judgement. The fatal defects that finally lead to their downfalls in Julius Caesar are Julius Caesar's arrogance and dynastic ambition, and Brutus' dogmatic idealism, faulty judgments, and ignorance. 
Julius Caesar's tragic flaws in this play include hubris and dynastic ambition. By demonstrating that Caesar was a nobleman of high rank, that he was a historical character with a tragic fault that led to his demise, and that Caesar accepted his fate of death and achieved honour and respect in his death, William Shakespeare illustrated Caesar as a tragic hero [19]. Oedipus is a tragic hero in Oedipus Rex according to the Aristotelian idea of tragedy because he is not flawless and possesses tragic defects. Oedipus' tragic defect, according to Aristotle, is inordinate pride (hubris) and self-righteousness. He also highlights several criteria that define a tragic hero [22].

\subsection{Karna's Tragic Flaw:}

Doomed from the start, it is frequently debated whether or not the outright consideration of Karna as a tragic hero is justified, given that his loyalty and friendship to Duryodhana call for rescuing his friend from aggressively achieving ruin, but Karna ended up on the wrong side of what loyalty means, driving not only his friend but also himself to a doomed fate. Through his princely bride Uruvi, Kavita Kane wonderfully justifies Karna's "mistake of judgement" as a method for satiating his rage after being humiliated as sutaputra in Draupadi's Swayamvar. As a mortal being, the desire to avenge one's insult for something decreed by fate is fully understandable, and Karna develops as a powerful yet marginalised character in the epic, despite being on the wrong side of morality and harbouring a distorted idea of loyalty. Despite drawing his karmic renditions towards achieving his dream of becoming the greatest archer of all time, it is his karma alone that surpasses his aim, marginalizing him and ultimately empowering Arjuna. Karna should probably focus on excelling in his own right rather than trying to outshine Arjuna, which would have condemned Karna for the rest of his life [23].

The very first impediment in Arjuna's path is erased with sambhavaparva, both by the guru, his beloved disciple Arjuna and by an apparent heavenly force that is most likely responsible for the impetus in the deeds that take place. The guru-shishya duo's next challenge comes in the guise of Karna, the suta, and also Surya Putra, the hero but also the tragic hero in the genuine sense. Karna is one of Mahabharata's most fascinating characters. He is a legend in his own right. His unrivalled warrior abilities were a perfect complement for his unwavering devotion to his comrade Duryodhana. While there is some debate as to whether Karna is a true hero or an anti-hero, Kavita Kane's book Karna's Wife: The Outcaste's Queen portrays Karna as a humane character with all of the divine attributes but mortal flaws that drive his karmic wheel towards his demise, thus justifying the tragic hero trait. Karna's death was caused by a combination of fate, personal attributes, and astute fighting plans. Although he had the aura of his father, Suryadev, the insults and humiliations he endured throughout his life sometimes eclipsed his brilliance [24].

Karna is one of the most complex characters of all complex characters in Mahabharata. He is both a highly principled and giving person, as well as someone prone to squandering his values. Karna had been robbed of a lot throughout his life. If Karna had simply those characteristics despised by Draupadi and others, he would have been one of the most obnoxious characters in the Mahabharata, rather than one of the most fascinating and attractive. His steadfast loyalty to Duryodhana and his generosity in giving gifts to those who come to supplicate for them are two characteristics that stand out. Unfortunately, he considers these two to be the sole categorical imperatives with which he must contend in his life. Karna reduces life to a basic set of rules in this way, failing to consider the complexities of his judgments. He is rarely challenged with a defining moment, but his genuine defining moment, and undoubtedly his best hour, occurs at the end when he is approached by his true mother, Kunti, shortly before the war begins [25]. Karna, to his credit, says he would rather be Radheya (his foster mother Radha's son) than Kaunteya then. He would not abandon his friend in his hour of greatest need.

\section{FINDINGS :}

Karna's entire life was spent trying to figure out who he was and to find an answer to the same. He had no idea if he was a Kshatriya or not, but he lived his life as if he was. Even his great friend Duryodhana could not accept him into Kshatriya society. Karna was unable to internalize or develop the value systems of the Kshatriyas or the Sutas. As a result, he appears as a confused individual who is at times a terrific person to adore and at other times nearly contemptible in his actions. Character is formed by being a part of a society, imbibing its ideals, and refining one's character through introspection and refinement. Karna was never given the opportunity. He was a Suta in a Kshatriya culture [26].

Karna's life also shows us how life is full of unrelenting choices; the options being limited. Friendship with someone who has aided at times of need and to whom one has sworn lifelong loyalty and friendship is admirable, but there must be a fine line drawn between this duty and other, more important 
responsibilities. It's never about one task being completed or not being completed; it's about conflicting duties. Karna could have kept his connection with Duryodhana without actively participating in Duryodhana and his siblings' manifestly despicable deeds. But, just as Bhishma defined his dharma as blind allegiance to the crown, Karna appears to have defined his dharma as supporting and actively engaging almost blindfolded in every misdeed of his friend. Not what is right or wrong, but what is the more acceptable alternative among the given range of options, none of which may be right or wrong. This necessitates character depth and strength, both of which Karna lacked [27, 28].

Karna is, without a doubt, a figure who, in Aristotelian terminology, possesses the classical features of a tragic hero, as well as a figure with a great deal of literary potential. Mrityunjay, a novel by the renowned Marathi novelist Shivaji Sawant, rewrites the Mahabharata story from Karna's perspective. Through the narratives of Duryodhana, Vrishali, Shona, Kunti, Krishna, and Karna, this work offers introspection on the epic. The Malayalam novel "Ini Njan Urangatte," written by P.K. Balakrishnan and released in 1973, is a literary tribute to the epic's unsung hero. As a result, Karma continues to be an excellent literary figure for writers today. This demonstrates the epic's literary potential as well as the breadth of characterization options available in the main text [29].

\section{CONCLUSION :}

Karna, despite his valiant efforts, was unable to alter his fate while still alive. However, when a ray of bright light left his body and blended with the sun beaming in the sky, he appeared to have atoned for his sins. After his death, he received immediate deliverance. In comparison, every one of the Pandavas had to spend a brief time in hell for their misdeeds before being allowed to enter Paradise. Given Karna's importance, we were tempted to wonder if he had been given his due as the eldest Pandava once Kunti had recognized her long-lost son. Perhaps the Mahabharata would not have been written at that time. At the very least, the epic would not have been in the form in which it has been handed down to us, and hence would not have been considered one of the great lyrical dramas ever written anywhere on the planet. To sum up, if there was one person in the entire Mahabharata who possessed all of the good traits that an ordinary human being may possess, it was Karna. No one was a more gracious donor than him. God had gifted him with a wonderfully attractive personality to go along with all of his superior mental and physical traits. However, as is common in such circumstances, he acquired some negative characteristics, largely through association, which led him to commit deeds that were opposed to his otherwise upright nature. But that is the way things are, so how could Karna be an exception? Nonetheless, he was extraordinary as a heroes' hero who lived and died for his principles and convictions, despite his many flaws. One might go on and on about Mahabharata's most outstanding character (except Shri Krishna), but there would still be something more to say about him. Karna will probably be remembered more as Duryodhana's loyal friend than as the eldest Pandava or Kunti's eldest son.

\section{REFERENCES :}

[1] Shivaramiah, S. (2018). Pampa Bharata. Bangalore: Kannada Pustaka Pradikara, 1, pp 1.

[2] Kumar, G. (2016). The Mahabharatans. Har-Anand Publication(p) Ltd. New Delhi. 13, 39-42,198201

[3] Nath, M. R. R. (2020). Ethical Dilemma of Karna in "The Mahabharata: A Critical Study of Karna's Character in The Light of Episode "The Temptation of Karna". IJESR, 10(3), 1-6.

[4] Kapoor, K. (2016). Karna (The Unsung Hero of Mahabharata: The Voice of the Subaltern). International Journal of Linguistics, Literature and Culture, 2(4), 15-25.

[5] Sukthankar, V. S. (2016). On the Meaning of the Mahabharata. Motilal Banarsidass. 49-54, 59.

[6] Hudson, E. T. (2006). Disorienting Dharma: Ethics and the Poetics of Suffering in the "Mahabharata". Emory University. 12-14.

[7] Vijayan, V. (2018). Unveiling The Doubly Marginalised: A Feminist Reading of Kavita Kane's Karna's Wife and Sita's Sister. Literary Endeavour, pp 136.

[8] Mishra,B,N.(2016). Charioteer Of Rays (Rashmirathi).VL Media Solutions. New Delhi. pp 70-148.

[9] Aswathy, P. V. (2020). Living on the Fringes: Addressing Deliberate Exclusions in Mahabharata through Kavita Kane's Karna's Wife-The Outcast's Queen. 17-23. 
[10] Adarkar, A. (2008). Psychological Growth and Heroic Steadfastness in the Mahābhārata. In Hermeneutics and Hindu Thought: Toward a Fusion of Horizons. Springer, Dordrecht 129,130132.

[11] Desai, R. (2019). Karna the Great Warrior. Harper Collins Publishers. Noida. 158-161.

[12] Kotru, U., \& Zutshi, A. (2015). Karna The Unsung Hero of the Mahabharata. Lead Start Publishing (P) Ltd, Mumbai. 191-200.

[13] Sarasamma, K, C. (2002). And Now Let Me Sleep. Sahitya Academy, New Delhi. 10(1), 102-106.

[14] Tagore, R., \& Kabir, H. (1959). Karna and Kunti. Indian Literature, 3(1), 1-9.

[15] Østerud, S. (1976). Hamartia in Aristotle and Greek Tragedy. Symbolae Osloenses, 51(1), 65-80.

[16] Dawe, R. (1968). Some Reflections on Ate and Hamartia. Harvard Studies in Classical Philology, pp 89-123.

[17] Stinton, T. (1975). Hamartia in Aristotle and Greek Tragedy. The Classical Quarterly, 25(2), 221254.

[18] Finkelberg, M (2006). Aristotle And Episodic Tragedy. Greece and Rome, 60-72.

[19] Mishra, R. K. Pre-Deterministic Catastrophes in the Life of Shakespeare's Tragic Heroes: An Analytical Study in Indian Vedic Perspective. JSTOR, (P-44-45 / 44-52)

[20] Lath, M. (1982). Understanding the Mahabharata: Iravati Karve's Yugant. Indian Literature, 25(5), 134-149.

[21] Mondal, D. (2009) Triumph of Destiny in the lives of Karna and Achilles. Global Journal of Human Social Science, 19(4), 21-22.

[22] Hull, R. (1993). Hamartia and Heroic Nobility in Oedipus Rex. Philosophy and Literature, 17(2), 286-294.

[23] Bremer, J. M. (1969). Hamartia Tragic Error in the Poetics of Aristotle and in Greek Tragedy. JSTOR, 15, 146-148

[24] Sanyal, S., \& Lane, K. B. (2015). Marginalized yet Empowered: A Study of Ekalavya and Karna from Mahabharata. IJELLH. 3(4). 615-622.

[25] Nussbaum, M. C. (2001). The Fragility of Goodness: Luck and Ethics in Greek Tragedy and Philosophy. Cambridge University Press.

[26] Rai, I. S. (2017). Delving Deep into Karna: Search of Self of a Divine Solitude. International Journal of Research in Social Sciences, 7(12), 710 -717.

[27] Manikutty, S. (2012). Why should I be Ethical? Some Answers from Mahabharata. Journal of Human Values, 18(1), 19-32.

[28] Rai, Bharathi S., \& Manjula, K. T. (2021). Re-inventing Karna of the Mahabharata with a Renewed Perspective- A Review of Literature. International Journal of Management, Technology, and Social Sciences (IJMTS), 6(2), 75-87.

[29] Vijay P. Prince. (2019). Propagation of Cultural Hegemony and Homogenization in Indian Society, The International Journal of Analytical and Experimental Modal Analysis, 11(11) 500 - 526.

$* * * * * * * * * *$ 